\title{
LATAH IN JAVA: A THEORETICAL PARADOX
}

\author{
Hildred Geertz
}

Latah is a rather singular psychological disorder with sharply patterned symptoms and a definite and limited distribution, which promises, because of this very specificity, to be a crucial and revealing case for the analysis of the role of cultural and social forces in determining the form and incidence of mental malfunction. Unfortunately, in spite of the considerable attention latah has been given in the literature, 1 no extensive empirical study of the disorder has yet been made. No psychiatric case-study of a single latah sufferer has ever been reported. Until such basic information has been gathered, our theories concerning latah's etiology remain mere hunches or at best logically consistent but unverified guesses.

This paper does not rectify this situation, but, on the contrary, in presenting some new data on the social and cultural context of latah in Java, only raises new questions. These data ${ }^{2}$ concern, first, the social position of latah sufferers, and secondly, the cultural significance of latah in Java, that is, the meaning, explicit and implicit, that latah has for the Javanese. The theoretical problems discussed are the relationship between structural social tensions and personal mental iliness, the way in which cultural patterns may influence symptom "choice," and the conflict between sociological, cultural and psychological explanations for the latah phenomenon.

The symptoms of latah are an involuntary blurting of obscene words or phrases, compulsive imitation of the words or actions of others, and compulsive unquestioning obedience

1. Bibliographies of the primary sources on latah can be found in David F. Aberle, "'Anctic Hysteria' and Latah in Mongolia," New York Academy of Sciences, Transactions, 1952, Ser. II, Vol. 14, No. 7, Pp. 291-297; and P. M. Yap, "The Latah Reaction: Its Pathodynamics and Nosological Position," Journal of Mental Science, 1952, No. 98, PP. 516-564.

2. The information regarding Javanese latah was gathered in the course of a two-year field study of family structure in an east-central Javanese town, in 1952-1954. This research was conducted under the auspices of the Center for International Studies, Massachusetts Institute of Technology, and was supported by the Ford Foundation. 
when ordered to perform actions which may be ridiculous, improper, or even dangerous. The stimulus to such behavior is any sudden loud sound, a tickling prod in the ribs, or an abrupt gesture. While an inanimate stimulus such as the sound of a door slamming, can bring on a latah attack, more usually the stimulus is interpersonal, and in fact, most often, in the form of deliberate, malicious teasing. The blurted obscenities, in Java at any rate, are always sexually obscene; there were no anal references noted, and no blasphemous or otherwise offensive words were used. In many of the cases that I observed, the obscene words were mixed in ordinary sentences, often replacing an ordinary word which was closely similar in sound to the obscenity. Thus, for instance, in one mild case, the latah was startled in the midst of a conversation about baskets. The Javanese word for basket resembles the word for horse, and the latah, meaning to say "Hand me that basket there," cried out "Go have intercourse with a horse," a sentence which the Javanese find deeply shocking. Most often the word blurted out is a term for male or female genitals. The actions or words which are compulsively imitated are not obscene, but are usually chosen by the teasing instigator as acts which are considered ludicrous. A popular one is getting the latah to take her clothes off, either by beginning to disrobe oneself so that the latah imitates and carries the action through, or by ordering her to do so.

In Java, and in most other places where latah has been reported, the only sufferers are older women. The condition may be mild or severe. A mild latah performs no imitative actions, but only, when severely startled, cries out an obscene word, a word which may be only moderately shocking. A severe latah not only does this often, sprinkling most of her conversation with involuntary and inappropriate obscenities, but also once stantled, remains in a highly vulnerable and suggestion-prone state for some time. A severe case is also easily led to imitate words and gestures, and to obey commands.

Persons severely afflicted with latah give an appearance of being under extreme tension; they seem to be highly wrought up and nervous. Those only mildly affected seem no different from the other people around them. Even the most extreme cases, however, are not kept from leading ordinary lives and, on the surface at any rate, from having normal relationships with other people. The condition seems to wax and wane: several cases were reported that were getting progressively more severe, while on the other hand I found several cases which had formerly been severe but reported that the symptoms had practically disappeared.

A latah is conscious during a seizure, and is fully aware of her condition. She is usually ashamed of it. She has no control over the outbursts, but she can try to avoid situations 
which are too disturbing. The persons around the latah have the power to aggravate or to minimize the condition by the way they behave toward her. A good many people look on a latah as fair game for entertainment and deliberately stir her up for their own amusement. Others find the obscenity too revolting to listen to, and are also sorry for the afflicted person, and try to move gently and speak quietly in her presence.

In Java, latah is popularly considered to be merely an odd condition, similar to stuttering and palsy. The sufferer is not thought to be abnormal or sick. The condition is sufficiently marked and standardized so that everyone who was questioned was in uniform agreement with others as to who was a latah and who was not. It is also a relatively common condition, and it took very little effort on my part to unearth the thirteen cases on which this report is based.

Symptom patterns which are almost identical to those have been reported in Malaya, Siberia (where it has been called arctic hysteria), Mongolia, among the Ainu of northern Japan, and among a 19th century Protestant communal sect known as the "Jumpers" of Maine and Canada. 3 There are also a number of less complete and less reliable reports of disorders with similar symptoms from a variety of other societies. While some of these cases may not prove on further examination to be identical to what is here called latah, nevertheless it is clear that latah is by no means confined to one society. On the other hand the fact that latah is not found evenly distributed around the world suggests that there may be some special peculiarity of the cultures of Java, Mongolia, the Ainu, etc., which is related to the presence of latah. The hypothesis that cultural factors are involved in its etiology is further reinforced by the information that in Malaya no Chinese become latah, except for those who have been reared in Malay households, and the similar fact that Japanese living in the Ainu region also seem to be immune, unless, again, they are brought up by Ainu. ${ }^{4}$

In Java, cases of latah were found to be confined within a particular, sharply definable, social group. Of the thirteen cases that I studied, all were women. Most were over fifty years old, although two mild cases were in their forties. All were, or had been, married and had had children. And all were, without exception, members of the urban lowerclass of landless, unskilled laborers. Although extensive inquiries were made, my colleagues and I could find no latah

3. Aberle, $\underline{O P}$. cit., and Yap, $\underline{\text { P. }}$. cit.

4. Yap, OP. cit., p. 551 . 
in any rural area; this absence is striking in view of the fact that the majority of Javanese are village-dwelling farmers. Also, there were no. latah among what might be called the urban middie and upper classes, that is the skilled and white-collar workers and the political elite. There is a fairly large immigrant Chinese population in Java, but there were no Chinese latah.5 Almost all the latah that I found were quite poor; the only one who was fairly well-off was a market woman who had suddenly become rich after the war and who remained awkwardly out of place socially among the members of her new class. Five out of the thirteen were petty peddlers in the town market, and six were maidservants or cooks for well-todo Javanese. At least five of the group had been servants to Dutch families before the war, and two had been mistresses of Dutch men who were drawn from the servant class. This proportion of latah who had been servants to the Dutch is very unusual, for the total number holding such jobs is very small. Thus the latah sufferers of Java appear to be confined to a sharply delimited sector of Javanese society: they are older women from the urban proletariat.

The social and cultural context of latah in Java can best be conveyed by illustrative description of the behavior of two not untypical latah, called here "Mbok Ti" and "Mbok Min," who were neighbors. They had been contacted through an informant who was a market woman. On discovering that I was interested in latah, she told me that her next-door neighbor was a latah, and invited me to her house to meet her. Accordingly, several days later, I paid a formal call on my informant, in the Javanese manner. Tea was brought out, and we engaged in the usual politely elegant and empty conversation expected in such a call. My hostess meanwhile sent her daughter next door for the latah, Mbok Ti. Mbok Ti, a woman in her forties, slipped in quietly and sat down next to the hostess. We continued our formal interchange of courtly phrases until suddenly the hostess jabbed her finger into Mbok Ti's ribs and Mbok Ti blurted an obscene word that I didn't catch. She was obviously extremely embarrassed, and got up immediately to leave. The hostess urged her to stay and talk with us, but Mbok Ti was still upset and replied something like, "Stay and talk vagina." This made her even more embarrassed and she left rapidly. After some time she came back again, but sat very quietly at some distance from the rest of us.

5. Edward Ryan, who was studying the chinese community in the Javanese town where this research was conducted, kindly carried out inquiries concerning the presence of latah among the Chinese, while Robert R. Jay, who was working at the same time in a village four miles away, investigated latah in that village and in several others in the same region. I am very grateful for their help. 
During the next weeks I paid several visits to Mbok Ti. She lived in a rundown bamboo shack with her husband and ten year old son. Before the war she had been a servant to a Dutch family that lived nearby. Today she worked at whatever odd jobs she could pick up. Her husband was a poor sharecropper. She never spontaneously mentioned her latah condition, and the circumstances of my field work at the time made it unwise for me to question her directly on it. she tended to be evasive, though polite, in speaking with me.

About a month later, Mbok Ti held a small feast in honor of her son's circumcision, and I attended it. All of the neighbors were there, politely drinking tea and conversing with proper subdued tones. A woman came in and Mbok Ti came up to me and said, "Here is a real latah, just watch. You should study her not.me." ( I had never mentioned my interest in latah; someone must have been talking to her.) With that she exclaimed in a loud voice to the new woman, "Dag!" the Dutch greeting, "Good-day!" The second latah, Mbok Min, immediately responded, "Dag!" several times, raising her hand automatically each time. When she paused, the first latah, Mbok Ti, started her up again. Then, tiring of this game, Mbok Ti cried out, "Merdeka!" the Indonesian slogan, "Freedom!" and Mbok Min imitated her, and again repeated it over and over. Mbok Ti then left us to take care of her guests, and Mbok Min quieted down. She was a very tense-looking woman, with large nervous eyes, of about sixty. She said nothing unless spoken to. It is the custom in Java at one of these feasts, for all the guests to urge each other politely to eat, saying over and over, "Mangga!" "Please eat!" Mbok Min had been sitting at the side for some time without speaking, when suddenly she burst out--this time without being teased--with "Mangga, mangga, mangga!" compulsively repeating the polite word and lts accompanying gesture, over and over. People then began to tease her and she grew more and more rattled, and in this upset condition began mixing obscene words in her speech. At one point she offered a cup of tea to someone, with the words "Please have some vagina." The word for tea has something of the same sound as the word for vagina.

Mbok Min was a widow of about sixty, living with her married daughter. Her husband had been a busdriver and her son-in-law was also a busdriver. She worked as a servant to a wealthy Javanese woman, and had previously been a servant to a Dutch family. I made some attempts to get acquainted with Mbok Min after meeting her, but she was always very tense and uncommunicative, and slipped away from my presence as rapidly as she could.

These two cases illustrate something more than the previously stated finding that latah in Java occurs among older urban women of low social status. It was no accident that my 
observations took place within the framework of formal and elegant social occasions. For etiquette and the values which animate it are central to Javanese culture, and, as I will attempt to show, the symptoms of latah are, in some obscure way, integrally related to the whole Javanese politesse pattern. If we set aside, for the moment, the usual individualcentered search for interpersonal and intrapsychic conflicts as explanatory factors in its etiology, and look instead on latah as an aspect of Javanese culture, as one set of standardized behavior patterns among many, we receive a strong impression that latah is a very "Javanese" way of expressing mental disturbance. In fact, it seems as though latah were tailor-made for Javanese, as if no more congenial form of psychological deviance could be adopted by a Javanese. This is a perplexing conclusion to reach in view of the fact that latah is by no means confined to the Javanese and appears in a variety of dissimilar cultures, such as the Mongol and the Ainu, and I can offer no immediate explanation of it. But let me document a little further this surprising congruence between latah and Javanese ways of thinking and feeling.

The actions associated with latah are more offensive to a Javanese than they might be to members of other cultures, for these acts directly flout behavioral standards which are not only accepted as customary by the Javanese but most deeply valued. A latah would be considered eccentric in any society but her eccentricity is peculiarly meaningful to a Javanese. She is excused for these uncontrollable actions, but they remain disgusting or (and in a sense this comes to the same thing) highly amusing.

In the first place, etiquette--stylized, graceful, formal actions and speech--is held by the Javanese to symbolize all that is finest in human relations. ${ }^{6}$ For them propriety and courtesy are not merely empty forms, but are expressive of that divine ingredient which sets off human beings from animals. Etiquette and religious ritual are closely allied in Javanese thinking: mystics see etiquette as the epitome of that external self-control and orderliness which is prerequisite to the internal Order that they seek. Javanese moralists see etiquette as the first step toward societal well-being, concrete and personal actions which cumulatively add up to the stability, predictability and good of the entire country. The essence of etiquette, to the Javanese, is elegant speech--long rhythmic sentences, high-flown words, euphuisms and elaborate circumlocutions. This identification of etiquette with the sacred and moral is of course related to the fact that Java, for most of its history, was politically dominated by a number of court cities, each with a royal aristocracy which had its center and

6. For a full description of the Javanese world-view and values, see Clifford Geertz, The Religion of Java, (Glencoe: The Free Press, 1960). 
source of legitimacy in a divine king. The aristocracy was intimately tied to the peasantry by countless personal and feudal ties, and the peasant looked to the nobility for spiritual and aesthetic leadership. Even under today's considerably different political conditions, the most isolated and ignorant peasants attempt, however crudely and clumsily, to adhere to the traditional courtly standards of propriety.

Thus it is that highly polished, delicately modulated speech is not only admired and enjoyed by Javanese but is also morally required. When a latah breaks this fragile and complex web with her blurted obscenities, she is not being merely odd, she is morally offensive.

Secondly, the Javanese are more than usually concerned with differential social status. This is perhaps not surprising, given their strong emphasis on formality and etiquette. For that is what the etiquette is all about: the expression of, or dramatization of, deference and of its reverse, the dignity of the superior. The Javanese image of society places every man either above or below any person he meets, with no one on a precisely equal level with anyone else. But while in practice these complex and minute distinctions are made, the social order is not so firmly fixed as to provide a feeling of secure position in it. Javanese seem always to be a little anxious over whether they are giving or receiving the full portion of deference due and they are easily offended by minor slights on their status. The result is an acute sensitivity to small indications of prestige or rank, and a constant concern over them.

It has been suggested that in several of the other societies in which latah occurs the seizures appear to be more easily provoked in the presence of a person of superior status. ${ }^{7}$ This seems to be true for Java too. In fact, it could be said that the compulsive imitation of the words and gestures of another person, and compulsive obedience to commands, are acts which are at base unconscious parodies of the social relationship between inferior and superior. At any rate a normal Javanese, watching a latah perform, must unconsciously perceive her actions as just such a parody, because of his overriding view of the social order as fundamentally a series of unequal relationships. In this way, Javanese culture provides yet another meaningful framework into which its members can place the latah's behavior.

There are other aspects of Javanese culture which are relevant in this connection. One of these is the marked reticence of the Javanese in any matter pertaining to sex. Any discussion or even mention of sexual acts, or of anything

7. Aberle, op. cit., p. 297. 
associated with sex, is frowned upon. No jokes are ever made about sexual matters. When a Javanese-made motion picture portrayed a kiss on the screen, large segments of the population protested vigorously, and the kiss sequence was deleted. In many cultures where sex is frankly and simply accepted, obscenity is merely mildly titillating. The Javanese attitude, however, is not simply puritan, since it is not held that sex is evil in itself. However, the public use of sexual words or references is a serious breach of etiquette, and, since etiquette is a matter of deepest religious and ethical significance, therefore obscenity is immoral. Here again the latah breaks the social taboo in an act which, if it were voluntary, would be severely disapproved by a Javanese.

Another theme in Javanese culture is a deep dread of psychological shock, a fear of being suddenly startled. This is an exceedingly important and pervasive concern. It appears for instance in the most prominent Javanese theory of the causes of disease. It is thought that any sudden sound or physical shock disorients a person so that he loses his bearings, his psychic defenses drop, and he becomes vulnerable to entry by one of the ever-lurking evil spirits who cause disease. A case of tuberculosis, for example, may be traced by a Javanese curer to a sudden fall that had been experienced by the patient. Infants are considered especially vulnerable to shock, and all the customs of infant care have a single intent, that of protecting the child against sudden noises, sharp physical discomfort, unpleasant tastes, and the like.

One small Javanese custom, performed on the child's fifth day of life, sums up this whole attitude. In the course of a ritual, someone suddenly claps his hands together sharply, making a loud crack and startling the infant into crying; this is thought to be a sort of magical immunization, a deliberate small shock which will help the child build up his own defenses against later greater ones. Javanese under almost all circumstances speak in quiet unemotional tones, so as not to disturb anyone. The pattern of preventing startling or disturbing stimuli extends even to Javanese music and drama which are smooth flowing, quiet, subtle and formal. I should emphasize that Javanese are no more easily startled than anyone else, but that what I am describing is a particular view of human nature that they hold. The latah's extreme vulnerability to startling stimuli stands out against this cultural background very sharply, a cultural background which gives it a significance which it would not have to the members of other societies.

These four cultural themes--the value for elegant and polite speech, the concern over status, sexual prudery, and the dread of being startled, are not unimportant patterns in Javanese culture. They are not merely concerns which all 
peoples have to varying degrees, but represent central characteristics of the Javanese. It is evident, given this set of values, that a latah, with her coarse, vulgar words, her involuntary parodying of her superiors, her compulsive breaking of sexual taboos, her extreme vulnerability to being startled, must be quite comprehensible at an unconscious level to any Javanese. The latah directly breaks several strongly enforced norms for social behavior, but the fact that her actions are involuntary excuses her from the usual disapproval, and makes this transgression of moral norms not offensive but entertaining. Her actions are all the funnier to a Javanese because of their closeness to the socially sacred.

What emerges from a purely cultural analysis of the latah's behavior is the conclusion that, at a covert level, the otherwise bizarre behavior of the latah is quite comprehensible to a Javanese spectator. The set of symptoms makes sense to him in terms of his understanding of human nature and the social order. This unconscious meaningfulness extends not only to the Javanese observer but also to the Javanese latah herself.

Thus it appears that latah is an unusually clearcut example of how the form of a set of symptoms may be determined primarily by a cultural tradition, a tradition which persists because of its congruity with basic themes in the wider culture. It may be that here is a case in which the culture presents to a certain--as yet unspecifiable--category of disturbed persons a coherent set of culturally meaningful behavior patterns, through which they find it possible to express their personal conflicts. It is reasonable to expect that when enough individual latah subjects have been adequately studied, the dynamics of their disease will be found to be similar to certain disorders of the western world. What distinguishes latah from many other types of mental malfunctioning, however, is the marked regularity and sameness of the form of its symptoms. It almost seems as though these individuals--who probably would be sick in any culture-instead of creating their own idiosyncratic symptoms, found a satisfactory solution to their conflicts in the pre-existing cultural pattern of latah.

The way in which culture could be said to "provide" a ready-made set of symptoms to a psychologically disturbed person may be better understood if a symptom is viewed as a kind of symbol, as a symbolic act by means of which the ill person can express his psychological dilemmas outwardly. As a symbol, the symptom gives meaningful external form to inner conflict--meaningful at an unconscious level, of course--to both the sufferer and his observer. Symbolic communication requires mutual agreement as to the significance of the symbol; that is to say, it requires culture. Latah may, in fact, be 
only one rather extreme manifestation of a more general fact: the involvement of culture in the process of symptom formation and symptom "choice."

A cultural analysis such as this can never explain a psychological disorder, nor does it imply that the symptoms cannot be analyzed in purely psychological terms. In fact, an adequate psychological explanation is precisely what is needed before we can understand why such a narrowly limited group of Javanese should "choose" this particular form of mental illness, while the larger majority do not.

So far, of all the socio-psychological interpretations advanced, the one that most closely fits the Javanese material is that of David F. Aberle, 8 which he based on published descriptions from Malaya, Siberia, North Africa and elsewhere, and on his own informants' reports on latah-like behavior in Mongolia. Aberle approaches the interpretation of the symptoms as psychological defenses and examines their content for clues to the inner conflicts underlying the disorder. He deduces that the defense mechanism involved in latah is a very simple form of "identification with the aggressor," and that the threat against which this defense is erected is that of being overwhelmed. He further suggests that the fantasied feared attack is a sexual one, citing several reports of the onset of latah as coupled with frightening dreams of being attacked by men or by male genitals. The coprolalic symptoms he interprets not so much as an identification with the aggressor but as an attempt to deal simultaneously with the threat from without and with unconscious material which has been aroused. He remarks that shouting obscene words permits a partial, but socially "meaningless" and therefore safe, expression of the unconscious impulse. Noting that in most of the areas reported the majority of cases are women from a subservient or submerged social position, and that attacks are most easily instigated by someone of authority or prestige, Aberle concludes:

My present guess (and it is only that) is that the latah's problem is one of disturbance and ambivalence with respect to submissive behavior, that this disturbance is based on an unconscious connection between submission and a dreaded and desired passive sexual experience akin to being attacked, and on the idea that the world stands ready to "overwhelm" the victim in this double sense. ${ }^{9}$

It is remarkable how well Aberle's theory fits with the social facts we have about Javanese latah. For all the

8. Op. cit.

9. Aberle, op. cit., p. 297. 
individuals that $I$ observed were in subservient social positions, both in terms of their general societal rank and also in their occupations. The proletariat to which they belong is a modern development, and lacks the support of a firm tradition which might provide such a lower-class status with intangible satisfactions, or at least the conviction that membership in it is a part of the natural order of things. The fact that so many latah were servants, and servants to Dutch families in particular, is further confirmation. One case was reported to me in which the onset of latah coincided with the woman's taking employment as a servant. The notion that an immediately operative factor for encouraging or discouraging latah behavior may be unequal status relationships within the social situation itself is further suggested by the account given above of the interaction between the two Javanese latah. There the one who was--at least for the moment--socially superior, was able not only to control her own acts, but also at the same time to provoke extreme attacks in the other woman. Another aspect of the Javanese case which gives further credence to this aspect of Aberle's thesis is the degree of preoccupation of the Javanese with status itself. If ambivalence concerning relative dominance is central to the psychodynamics of latah, how much more intensely such ambivalence must be felt by a Javanese who sees every human relationship in these terms.

One element implicit in Aberle's hypothesis is not supported by the Javanese material. This is the apparent assumption that strain over subordinate status is necessarily emphasized by a woman's social role. Javanese women's roles are not particularly subservient, burdensome, or restricted; in fact, most Javanese women are assertive and self-confident, while their husbands are comparatively passive and permit their wives to dominate them. This was true also of those women who were latah. However, it may be that their very freedom accentuates an ambivalent desire for and fear of submission. On the other hand, Aberle may have based his remarks on an assumption that there are psychosexual conflicts which are peculiar to women irrespective of culture and social position, conflicts which, however, can be socially exacerbated or eased. A theory of this sort would be supported by the fact that all of the Javanese women studied were approaching or past menopause.

In summary, latah presents an intriguing paradox to the student of culture and mental disorder. For here is a disease which is found in a variety of very different cultures, a disease which has a very specific symptom syndrome and which seems to afflict people in very similar social positions no matter where it appears. Explanations which are purely psychodynamic--such as those which tag latah as "hysteria," "hysteriform," "shock neurosis," "neurological disorder akin to LaTourette's disease"--are insufficient, for they cannot 
account for the presence of the disease in particular social groups. What is required is a systematic comparison of the societies to determine the common elements which might give rise to the same form of mental disorder in all of them. The common elements sought should be ones of sufficient generality to be easily "translated" from one society to another, such as similarly patterned experiences in infancy, commonalities in the role of women, or similarities in the stratification systems, which might give rise to similarly structured social stresses. All of these factors are of a kind which I would term "sociological" as opposed to "cultural,"l0 and should vary independently of the various belief-systems, ideologies, world-views, etc., found in each particular society.

The paradox lies in the fact that when one of these societies was studied closely for the place and meaning of latah in its culture, it was found that latah is remarkably congruent with themes which are both unique to and central to it. If it were not for the presence of latah elsewhere in the world, one would be tempted to conclude that the reason for its occurrence in Java is self-evident, that its congruence with Javanese culture sufficiently accounts for its appearance there.

This is the sort of paradox, obviously, which arises either where there is insufficient data or inadequate conceptualization. Whether, when all the returns are in, latah turns out to be basically a response to idiosyncratic or constitutional psychic weaknesses, to interpersonal strains of social origin, to culturally determined ambivalences, or--most likely--to some combination of these, awaits further inquiry. Each of these approaches has some cogency, but none of them can at present be fully reconciled with the others.

10. As defined by Talcott Parsons and Edward Shils, Toward a General Theory of Action (Cambridge, Mass.: Harvard University Press, 1951). 